\title{
Między codziennością a „państwem Platona”. Racjonalistyczne aspekty twórczości Łukasza Opalińskiego
}

Istotny wyróżnik twórczości Łukasza Opalińskiego stanowi obecny w niej „pierwiastek intelektualny”. Znamionuje on dokonania pisarza od najmłodszych lat wykazującego zamiłowanie do książek, które - ugruntowane dzięki wszechstronnej edukacji odbywanej w latach młodzieńczych w Kolegium Lubrańskiego, na uniwersytetach w Lowanium, Orleanie i Padwie - w wieku dojrzałym przyniosło efekt w postaci zgromadzenia imponującego księgozbioru, dobitnie poświadczającego rozległość zainteresowań jego właściciela ${ }^{2}$. Renoma erudyty, jednego z najlepiej wykształconych ludzi epoki ${ }^{3}$, konweniuje $\mathrm{z}$ opinią o stylu życia tego arystokraty, który w aktualne sprawy publiczne angażował się dużo powściągliwiej od swego brata - rzutkiego, pełnego ambicji politycznych wojewody poznańskiego Krzysztofa Opalińskiego ${ }^{4}$. Bardziej niż bieżące sprawy polityczne czy majątkowe absorbowało Łukasza Opalińskiego studiowanie książek i rozmyślanie o projektach reform Rzeczypospolitej5. Przesiadywanie przy lekturach (prowadzące do zaniechania jazdy konnej, myślistwa czy zajęć gospodarskich) sprawiało, że jego brat wyrażał obawy co do zdrowotnych skutków takiego sposobu spędzania czasu, pisząc w jednym z listów: „Dla Boga! i styjesz WMć, i zdrowiu tym non consules. Są psi, jest gospodarstwo - około

I C. Backvis, Panoramapoezji polskiejokresu baroku, t. 2, przeł. W. Błońska-Wolfarth, A. i K. Choińscy, G. Majcher, red. A. Nowicka-Jeżowa, R. Krzywy, Warszawa 2003, s. 45.

${ }_{2}$ Zob. K. Schuster, Biblioteka Lukasza Opalińskiego, marszalka nadwornego koronnego (1612-1662), Wrocław 1971.

3 Ibidem, s. 6, 16, 44.

${ }_{4}$ Zob. A. Sajkowski, KrzysztofOpaliński, wojewoda poznański, Poznań 1960.

5 R. Pollak, O listach Krzysztofa Opalińskiego do brata Łukasza, w: Wśród literatów staropolskich, Warszawa 1966, s. 266. 
tego się też krzątać, by się zaś nie rzekło: «Heus, heus, philosopharis»" ${ }^{6}$.

Zainteresowania filozoficzne - osobliwie skomentowane w przywołanym zabytku epistolografii staropolskiej - wkomponowują się w kontekst biografii intelektualnej Łukasza Opalińskiego. Badacze jego twórczości nie bez powodu wskazywali na różne aspekty uwidaczniającej się w niej problematyki filozoficznej. W perspektywie zagadnień podjętych w tej pracy na szczególną uwagę zasługuje to, że analiza filozoficznych treści pism Opalińskiego zaowocowała ustaleniem racjonalistycznych źródeł poglądów politycznych i prawnych wyłożonych w traktacie Pauli Naeoceli de o ciis libri tres (1659)7. Charakteryzując dokonania pisarza, wskazywano także na cechujący jego postawę "racjonalizm polityczny" ${ }^{8}$. Stwierdzono, że w racjonalizmie i rozsądnym umiarze tkwią zasady przyświecające metaliterackiej refleksji zawartej w Poecie nowym ${ }^{9}$. Nie bez racji już u progu ubiegłego stulecia o „pracy literackiej” barokowego twórcy pisano jako o działalności „rozumnej, wytrawnej, rozległej” "

Jednak racjonalizm Łukasza Opalińskiego rozpatrywano zwykle bardzo ogólnie oraz fragmentarycznie, ograniczając się do wybranych utworów. Intencją tej pracy jest więc analiza całokształtu dokonań pisarza i ustalenie roli, jaką racjonalizm odegrał w różnych sferach jego przemyśleń. Szczególnie interesować mnie będzie to, jak definiował on miejsce rozumu w strukturze ontycznej człowieka, jak charakteryzował możliwości poznawcze rozumu, jak racjonalistyczne inspiracje uwidoczniły się na polu jego filozofii politycznej oraz w dziedzinie refleksji dotyczącej teorii literatury. Odtworzenie wymienionych aspektów twórczości autora Rozmowy Plebana z Ziemianinem (1641) pozwoli wydobyć jeden z symptomatycznych rysów postawy pisarza o aspiracjach myślicielskich, o wyraźnych cechach intelektualnej i artystycznej „osobności” ${ }^{\text {II }}$, odróżniającej go od wielu innych twórców epoki baroku.

${ }^{6}$ Listy Krzysztofa Opalińskiego do brata Łukasza 1641-1653, red. R. Pollak, oprac. M. Pełczyński, A. Sajkowski, Wrocław 1957, s. 4.

7 C. Kunderowicz, Poglady filozoficzno-prawne Łukasza Opalińskiego, Warszawa 1939, s. 23, 38, 47, 65, 77, 81. O koncepcji prawa w twórczości Łukasza Opalińskiego zob. też uwagi E. Jarry, Historia polskiej filozofii politycznej, 966-1795, Londyn 1968, s. 209-210.

${ }^{8}$ S. Grzeszczuk, Wstę, w: Ł. Opaliński, Wybór pism, oprac. S. Grzeszczuk, Wrocław 1959, s. CLVIII.

9 E. Sarnowska-Temeriusz, Droga na Parnas. Problemy staropolskiej wiedzy o poezji, Wrocław 1974, s. 203. Zob. też s. 201-202.

to A. Brückner, Znakomitsi pisarze wieku XVII. I. Łukasz Opaliński, „Pamiętnik Literacki” 1902, s. 218.

II Posługując się tą formułą, nawiązuję do charakterystyki innego wybitnego twórcy doby baroku, którą sugestywnie zarysował C. Backvis, „Osobnośc” jako 
Dla rozważanej problematyki największe znaczenie ma to, że postawa filozoficzna Opalińskiego ukształtowała się na podłożu inspiracji płynących ze starożytności i średniowiecza, wśród których szczególną uwagę zwracają schrystianizowany stoicyzm, tradycja arystotelesowsko-tomistyczna, w pewnym stopniu także myśl augustyńska oraz idee humanizmu renesansowego ${ }^{\mathrm{I} 2}$. Uwydatniamy ów odległy historycznie rodowód koncepcji barokowego pisarza, gdyż w zasadniczej mierze właśnie w dawniejszej filozofii zakorzeniony był jego racjonalizm. Podkreślając ten stan rzeczy, warto dodać, że zainteresowanie naszego twórcy budził także głośny w jego czasach racjonalizm René Descartes'a, którego sławna Rozprawa o metodzie (1637), wraz z innymi pismami francuskiego filozofa, znajdowała się w księgozbiorze marszałka nadwornego koronnego ${ }^{\mathrm{I} 3}$.

Istotne ustalenia dotyczące rozumu przedstawił Opaliński we wspomnianym dziele Deofficiis, zamieszczając je w partiach poświęconych duszy ludzkiej. Opowiadając się za dychotomiczną koncepcją duszy, wyróżnił jej część doskonalszą, wyposażoną $\mathrm{w}$ rozum, zawiadujący pamięcią, intelektem i wolą oraz przeciwstawiający się mniej szlachetnej - pożądliwej i podlegającej wzruszeniom - części duszy ${ }^{\mathrm{I}}$. Eksponowany w ten sposób wysoki status ontyczny rozumu przejawia się dalej w utożsamieniu natury człowieka właśnie z rozumem oraz w orzeczeniu (za świętym Tomaszem z Akwinu), „że rozum ludzki jest oświecony i kierowany przez Boga, wskutek czego rozum tworzy zasadę należytego postępowania człowieka" ${ }^{5}$. Rozum bowiem dysponuje zdolnością pojęcia reguł prawa naturalnego, których źródło stanowi „Prawda tkwiąca w Bóstwie” (OFF, s. 215) ${ }^{\mathrm{x} 6 .}$

Z tą wysoką oceną rozumu korespondują spostrzeżenia przyobleczone $\mathrm{w}$ inną szatę słowną, zapisane przez Opalińskiego w Poecie nowym (powst. ok. 1661-1662). Od poetyckiego wykładu zagadnień z dziedziny teorii poezji trudno oczekiwać pojęcio-

temat w twórczości i osobowości Stanisława Herakliusza Lubomirskiego, w: Stanistaw Herakliusz Lubomirski. Pisarz - Polityk - Mecenas, red. W. Roszkowska, Wrocław 1982, s. 25-49.

${ }^{12}$ C. Kunderowicz, op.cit.

s K. Schuster, Biblioteka Łukasza Opalińskiego, s. 138-139.

${ }_{4}$ C. Kunderowicz, op.cit., s. 32.

I5 Ibidem, s. 37.

${ }^{16} \mathrm{~W}$ ten sposób oznaczam cytaty z traktatu De officiis (OFF). Po skrócie wskazuję numery stron w edycji: Ł. Opaliński, Deofficiis, przeł. T. Włodarczyk, w: Filozofia i myśl społeczna XVII wieku, t. 1, oprac. Z. Ogonowski, Warszawa 1977. Na identycznych zasadach oznaczone są odwołania do innych utworów: $\mathrm{R}=$ Rozmowa Plebana $z$ Ziemianinem, OP = Obrona Polski (przeł. K. Tyszkowski), $\mathrm{CN}=$ Cośnowego, $\mathrm{PN}=$ Poeta nowy. Utwory te przytaczane są za wydaniem: Ł. Opaliński, Wybór pism, oprac. S. Grzeszczuk, Wrocław 1959. 
wej ścisłości odnoszącej się do materii filozoficznej, stanowiącej przedmiot omawianego uprzednio traktatu. Mimo oczywistej odmienności poetyki obu utworów (rzutującej na sposób ujęcia kwestii filozoficznych), trudno nie zauważyć, że drugi z nich wyraźnie odwołuje się do rozpowszechnionej niegdyś teorii „wielkiego łańcucha bytu” ${ }^{77}$, wyjaśniając w jej ramach miejsce istoty ludzkiej w hierarchii stworzeń. Kwestie, o których mowa, podjęte zostały we fragmencie Poety nowego:

Bo jeźli rzeczy o duszę nie mają

Uwagi, swe miejsce przyzwoite mają,

Jeźli stworzenie wszelakie i zgoła

Zwierzęta, ptastwo, ryby, drzewa, zioła,

Każde z nich ma swe własne przyrodzenie,

W którym uznawa całe nasycenie;

Gdy rzeczy martwe lub tylko żyjące

Mają dobro, swej naturze służące,

Dalekoż więcej w rozum ozdobiony

Człowiek mieć musi kres swój przyrodzony,

A pewnie inszy od nierozumnego

Stworzenia, bowiem nie jest zarównego

Rodu i stądże inszej szczęśliwości

Chce, należytej do swojej godności. (PN, s. 321-322)

Tekst nie pozostawia wątpliwości co do tego, że rozum stanowi wyróżnik pochodzenia człowieka i eschatologicznego celu jego życia, odmiennego od tych rodzajów „szczęśliwości”, w których znajdują spełnienie stworzenia nierozumne. Rozum jest też wyznacznikiem przynależnej istocie ludzkiej „godności”. Tę ostatnią kategorię wolno wyjaśniać $\mathrm{w}$ duchu piśmiennictwa dotyczącego godności człowieka, w którym w eksponowaniu „dignitas bominis chodzi o człowieka jako o wartość obiektywną, ugruntowaną samym jego miejscem w hierarchicznie rozumianej strukturze całości bytu i jego szczególnym uposażeniem jako bytu zajmującego określone miejsce w tej całościowej strukturze" ${ }^{18}$.

Jednym z najważniejszych przejawów wysokiej wartości (a więc również „godności”) rozumu są jego kompetencje poznawcze, przedstawiane przez Opalińskiego również w ujęciu odmiennym od zreferowanego tu wcześniej. Zauważa on bowiem, że kompetencje te pozwalają rozumowi na częścio-

${ }_{7}$ Zob. A.O. Lovejoy, Wielki łańcuch bytu. Studium z dziejów idei, przeł. A. Przybysławski, Warszawa 1999.

I8 J. Domański, $Z$ dawnych rozważań o marności i pogardzie świata oraz nedzy i godności człowieka, Warszawa 1997, s. 138. 
we wniknięcie w boską wiedzę o losach świata. Dowodzi tego stwierdzenie, które w Rozmowie Plebana z Ziemianinem zostało wplecione w rozważania o ustroju Rzeczypospolitej: „A lubo wyroki Pańskie skryte są, rozsądek jednak baczny dochodzić ich nieco może, bo i te śrzodkami swymi pewnymi przychodzą do skutku” (R, s. 60). Wyraźny religijny profil poglądów Opalińskiego skłania do konstatacji, iż rozum, ujawniający się tu pod postacią „,bacznego” rozsądku, nie odczytuje zarysów rządzącej światem, pojmowanej po stoicku, rozumnej konieczności, lecz na podstawie obserwacji zdarzeń zbliża się do cząstkowego poznania ich ukrytej logiki, w pełni znanej wyłącznie Bogu. Katolicka religijność pisarza każe wykluczyć interpretację, zgodnie z którą widniejące w cytowanym tekście „wyroki Pańskie” należałoby wyjaśniać w duchu teorii predestynacji.

Religijność barokowego twórcy pozwala wyjaśnić także to, że granica racjonalnych poszukiwań była dla niego oczywistością niepodlegającą dyskusji, wymagającą tego, aby dociekliwy rozum poddać obediencji wiary. W De officiis z całą ostrością oświadczał, że „ludzkie rozumowanie” i podążanie drogą „ciekawskich poszukiwań" przeciwne jest nieodmiennej regule wiary, „która nakazuje wierzyć, a nie poszukiwać”, a ostatecznie prowadzi do herezji (OFF, s. 696). Wielce pożądana jest też czujność wobec takiej wykładni wiary, która „sprzyja ludzkim umysłom", zaś absolutyzując racjonalne zasady poznania, nadwątla istotny rdzeń wiary religijnej, gdyż „nie nakazuje wierzyć w to, czego nie pojmiesz; odrzuca to wszystko, co przekracza możliwość poznania albo jest z nim sprzeczne” (OFF, s. 697). Co za tym idzie - sprzyja groźnej liberalizacji norm życia religijnego, „otwiera drogę do nieba nazbyt szeroko, podczas gdy wąska jest ścieżka tam prowadząca” (OFF, s. 697). Na marginesie odnotowanych uwag dodajmy, że dezaprobatę pisarza wobec racjonalnych inicjatyw odnoszących się do życia religijnego wolno wiązać ze współczesnymi mu kontrowersjami w tej materii, zwłaszcza tymi, które budziła ariańska doktryna „religii zgodnej z rozumem", poddawana frontalnej krytyce tak ze stanowiska katolickiego, jak z pozycji innych konfesji chrześcijańskich.

Godne odnotowania jest to, że kompetencje i ograniczenia poznawcze rozumu stały się przedmiotem uwag Opalińskiego widniejących w enumeracji otwierającej Coś nowego (1652) ${ }^{\text {I9 }}$.

I9 Szerzej o tym utworze: J. Krzyżanowski, Lukasz Opaliński i jego paszkwil na Radziejowskiego, w: idem, Od średniowiecza do baroku, Warszawa 1938, s. 339-351; S. Grzeszczuk, Łukasza Opalińskiego „Coś nowego” - strategia pamfletu, w: idem, Kochanowski i inni. Studia, charakterystyki, interpretacje, Katowice 1988, s. 346-373; M. Szczot, Paszkwil czy satyra menippejska? „Coś 
Osnową wyliczenia inicjującego ten utwór jest słowo „Coś”. Wywołuje ono najrozmaitsze asocjacje oraz staje się kanwą refleksji o paradoksach wpisanych w najambitniejsze przedsięwzięcia poznawcze podejmowane przez ludzi:

[...] wielka to rzecz: pojąć Coś; mądrych głów i głębokich mózgów jedyna zabawa jest: [pojąć] skrytego Coś. O tym najwięcej mówią, piszą, dyskurują, a częstokroć daremnie, bo Coś tym się bardziej, tym głębiej kryje; bo jak poznają i zrozumieją, to już Coś nie jest Coś i potąd tylko jest w szacunku, pokąd się jeszcze o nie pytają, pokąd jeszcze jest tu Coś. (CN, s. 235)

Lecz bywa i tak, że poznawczy impet ludzkiego rozumu nie jest władny wniknąć w najtajniejsze aspekty rzeczywistości w zasady ładu wszechświata, w najgłębszą strukturę żywiołów, w tajemnice świata nadprzyrodzonego. Wtedy owo „Coś” - jak czytaliśmy wcześniej, do czasu tylko budzące nasz respekt i stymulujące umysł - zmienia swój sens i staje się finalnym efektem wysiłków poznawczych rozumu:

[...] Coś jest rzeczy, których rozum pojąć nie może, największy i ostatni tytuł. Na przykład o niebie, o żywiołach, aniołach, a nawet i o Bóstwie samym siłę nadyskurowawszy, tandem wszytko kończemy, że to jest niepojętego Coś. (CN, s. 235-236)

Pora przypatrzeć się, jak racjonalizm współokreślił ideowy koloryt stworzonej przez Opalińskiego filozofii politycznej. Wejrzenie w niektóre jej aspekty trzeba poprzedzić uwagą natury ogólnej.

Otóż w jego pismach z tej dziedziny rozpatrywanych en bloc próżno szukać myślowej spójności i konsekwencji zarówno w zakresie oceny ustroju Rzeczypospolitej, jak też w sferze propozycji jego naprawy. Ogłoszona anonimowo Rezmowa Plebana z Ziemianinem to utwór, który doczekał się spolaryzowanych interpretacji co do preferowanych przez Opalińskiego rozwiązań ustrojowych. Dostrzeżono więc w autorze zwolennika absolutyzmu monarszego ${ }^{\circ \circ}$, zasugerowano jednak, że „w żadnym wypadku nie myślał on o wprowadzeniu tego systemu rządów

nowego" Łukasza Opalińskiego, w: eadem, Od Herkulesa do „żony wyćwiczonej”. W kręgu staropolskich satyr menippejskich, Poznań 2013, s. 129-166.

${ }_{20}$ Zob. S. Grzeszczuk, Stan i potrzeby badań nad biografią i twórczościa Łukasza Opalińskiego, „Pamiętnik Literacki” 1958, z. 2, s. 355, 372-373; idem, Ideologia $i$ źródła sejmowe „Rozmowy Plebana z Ziemianinem” Łukasza Opalińskiego, „Pamiętnik Literacki” 1960, z. 4, s. 296, 298-300, 304-305, 307. 
do Polski” ${ }^{21}$. Dzieło odczytano również jako wyraz apologetycznego stosunku pisarza do współczesnej mu formy demokracji szlacheckiej, formułującego jedynie umiarkowane, ostrożne postulaty reform ustrojowych ${ }^{22}$. Obok kontrowersji dotyczących ideowego przesłania Rozmowy - być może celowo ujętego przez autora niejednoznacznie ${ }^{23}$ - odnotować wypada również to, że praca Opalińskiego Polonia defensa contra Ioan[nem] Barclaium (1648) przyniosła gloryfikację sarmackiego republikanizmu i obronę rodzimego wzorca kultury. Ponieważ adresatem tej publikacji miał być czytelnik zachodnioeuropejski - Opaliński dał $\mathrm{w}$ niej refutację stereotypowych, zafałszowanych opinii o Polsce przedstawionych $\mathrm{w}$ głośnej książce nowołacińskiego pisarza Johna Barclaya Icon animorum - nie pojawiły się w niej akcenty krytyczne, tak charakterystyczne dla Rozmowy Plebana z Ziemianinem oraz dla utworu Coś nowego. Wspominając o komplikacjach rozważań Opalińskiego na temat ustroju Rzeczypospolitej - i szerzej: na temat optymalnej formy organizacji państwa - dodajmy, że osobne miejsce zajmuje pod tym względem traktat De officiis, zawierający ,systematyczny wykład filozofii państwa, w którym pisarz wypowiada się wyraźnie za absolutyzmem jako najlepszym systemem rządów” ${ }^{24}$. Dzieło to ogłoszone zostało po raz pierwszy w Krakowie w nakładzie zaledwie 20 egzemplarzy, a nazwisko autora nie zostało ujawnione (spośród kolejnych siedmiu wydań tylko jedno miało miejsce w kraju, aż sześć ukazało się za granicą ${ }^{25}$. Editio princeps ujrzała więc światło dzienne w okolicznościach skutecznie ograniczających recepcję napisanego po łacinie traktatu. Być może elitarny charakter publikacji wynikał $\mathrm{z}$ niechęci, jaką jego twórca światły wielmoża - żywił wobec angażowania się w dyskusję polityczną, której stroną byłaby szeroka publiczność szlachecka.

Ciekawym aspektem filozofii politycznej Łukasza Opalińskiego jest to, że niezależnie od zrelacjonowanych komplikacji a więc niezależnie od sympatii autora dla takiej czy innej formy rządów oraz od różnego adresu czytelniczego poszczególnych dzieł - stale podkreślał on doniosłość racjonalnej organizacji

${ }_{21}$ W. Czapliński, O Polsce siedemnastowiecznej. Problemy i sprawy, Warszawa 1966, s. 99.

${ }^{22}$ K. Schuster, W sprawie pogladów monarchicznych Łukasza Opalińskiego, w: O naprawę Rzeczpospolitej XVII-XVIII w. Prace ofiarowane Wtadystawowi Czaplińskiemu w 60 rocznicę urodzin, red. J. Gierowski, Warszawa 1965, s. 105, 107.

${ }_{23}$ Zob. C. Hernas, Barok, Warszawa 1978, s. 249.

${ }_{24}$ Z. Ogonowski, Filozofia polityczna w Polsce i tradycje demokracji europejskiej, Warszawa 1992, s. 150. Zob. też s. 151-156.

${ }_{25}$ Z. Ogonowski, Wiek XVII, w: J. Domański, Z. Ogonowski, L. Szczucki, Zarys dziejów filozofii w Polsce, Warszawa 1989, s. 442. 
struktur państwa. W sposób niepodlegający wahaniom opowiadał się za racjonalnym trybem rozwiązywania niedomagań życia zbiorowego. W odwołaniach do rozsądku i rozumnej odpowiedzialności za dobro wspólne upatrywał ważnego remedium na niepokojące zjawiska współczesności. Racjonalizm urasta zatem do rangi jednego z głównych motywów jego filozofii politycznej.

Przedstawiona dalej dokumentacja źródłowa tej obserwacji zyska na wiarygodności, jeśli przypomnimy, że myśl społeczna XVII stulecia dwoma drogami dążyła do korekty licznych problemów zbiorowego życia ludzi. Nadzieje na poprawę wiązano z oddziaływaniem na człowieka odwołującym się do tradycyjnych wartości religijnych. Możliwości ulepszenia upatrywano również w poszukiwaniu takich rozwiązań, na których zasadność wskazywał rozum ${ }^{26}$. Ujęcie religijne i ujęcie racjonalistyczne - niekiedy traktowane $\mathrm{w}$ kategoriach przeciwstawnych propozycji spojrzenia na sprawy społeczne - częściej jednak były ze sobą zintegrowane, gdyż uznawano, że to Opatrzność Boża przemawia głosem rozumu stanowiącego reguły porządku właściwego dla życia zbiorowości zorganizowanej w państwo ${ }^{27}$.

Teologiczne, a równocześnie rozumowe uprawomocnienie władzy państwowej jest przedmiotem wykładu Opalińskiego w De officiis. Czytamy tu, że racjonalna konieczność decyduje o istnieniu państwa, gdyż analogicznie do tego, jak „poszczególnych ludzi natura skłania do zakładania rodzin, tak znów rozum skłania z koniecznością poszczególne rodziny do tego, by łączyły się w państwa" (OFF, s. 219). Zbawienne i dla jednostek, i dla rodzin połączenie się w ,jeden organizm państwowy” możliwe jest dzięki istnieniu władzy, której nieodzowność unaoczniamy sobie właśnie dzięki pouczeniom rozumu poddanego boskiemu zwierzchnictwu:

Tę świadomość, którą dyktuje nam rozum, że władza państwowa jest konieczna, Bóg nie tylko zaszczepił w naszych umysłach, ale również umocnił wypowiedzią własną lub swych przedstawicieli, gdy stwierdził, że wszelka władza od niego pochodzi, a także, że każdy winien być jej posłuszny; jak również przez to, że nakazał, iż władzy należy oddawać to, co się jej należy.

Rodzaj ludzki poszedł więc za wskazaniami rozumu, jak również tego, który rozumem kieruje - Boga, gdy przekazał najwyższą władzę albo jednostce, albo radzie, albo zgromadzeniu obywateli. (OFF, s. 220)

${ }^{26}$ W. Voisé, Myśl społeczna siedemnastego wieku, Warszawa 1970, s. 44.

27 Ibidem, s. 330. 
Spośród wymienionych typów państwa - monarchii, arystokracji i demokracji - optymalny jest pierwszy z nich (Opaliński odrzuca rozwiązania polegające na łączeniu różnych modeli ustrojowych). Jedynie władza królewska może zaradzić dotkliwym następstwom grzechu pierworodnego uwidaczniającym się wżyciu zbiorowości. Upadek pierwszych rodziców poważnie bowiem uszczuplił tę miłość, która początkowo łączyła wszystkich ludzi oraz w naturalny sposób prowadziła ich do jedności i zgody. W sytuacji trwałego skonfliktowania ludzi tę pożądaną jedność osiągnąć jest bardzo trudno. Jej wprowadzeniu i utrwaleniu w państwie najpełniej sprzyjają rządy monarsze ${ }^{28}$, które - podkreślmy - w doktrynach politycznych i prawnych wieku XVII uznawano za formę sprawowania władzy w najwyższym stopniu odpowiadającą wymogom racjonalności. „Król jest symbolem rozumu" ${ }^{29}$, a doktryny absolutyzmu monarchicznego ukazują go jako istotę górującą rozumem nad poddanymi, traktowanymi jako tłum powodowany namiętnościami, niemal zupełnie pozbawiony zdolności racjonalnej oceny rzeczy. Wyrastając ponad masy rozumem (a także doświadczeniem, którego summę stanowi historia), monarcha podejmuje decyzje trafne, dobrotliwe, zgodne z jego oceną tego, co stanowi „dobro ogółu”. Postanowieniom panującego należy się posłuch, nawet jeśli rządzonym jawią się jako nieprzeniknione - niedopuszczalną zuchwałością $\mathrm{z}$ ich strony byłoby ingerowanie $\mathrm{w}$ arkana sztuki rządzenia ${ }^{\circ}$. Abstrahując od tego ogólnego wydźwięku teorii monarchicznych, zaznaczmy, że w oczach szlacheckiej publiczności nie mogłyby zyskać aprobaty ani pochwała absolutyzmu wyrażona przez Opalińskiego w De officiis, ani też jego opinie na temat sprawowania władzy w innych formach ustrojowych. Zwłaszcza opowiedzenie się na rzecz podejmowania decyzji rządzących większością głosów oraz odmówienie poddanym prawa do oporu wobec najwyższej władzy, nawet gdy decyzje władzy wydają się niesłuszne i sprzeczne z poczuciem sprawiedliwości ${ }^{\mathrm{I}}$.

Optyka Rozmowy Plebana z Ziemianinem zasadniczo odbiega od zarysu państwa idealnego ukazanego w De officiis, kreowa-

${ }_{28}^{8}$ Z. Ogonowski, Filozofia polityczna w Polsce..., s. 152. Zob. ponadto: E. Jarra, Jedność obywatelska w dziejach filozofii prawa, Warszawa 1937; C. Backvis, Wymóg jednomyślności a ,wola ogótu”, w: Renesans i barok w Polsce. Studia o kulturze, wybór, oprac. H. Dziechcińska, E.J. Głębicka, Warszawa 1993, s. 282-300.

${ }_{29}$ H. Olszewski, M. Zmierczak, Historia doktryn politycznych $i$ prawnych, Poznań 1994, s. 122. Zob. też s. 123.

$3^{\circ}$ Zob. K. Grzybowski, Historia doktryn politycznych i prawnych od państwa niewolniczego do rewolucyj burżuazyjnych, Warszawa 1967, s. 310-311.

${ }^{3}$ Zob. Z. Ogonowski, Filozofia polityczna w Polsce..., s. 152. 
nego przez Opalińskiego zgodnie z religijnymi i racjonalistycznymi pryncypiami. Symptomatyczny jest fragment Rozmowy, w którym wizja wzorcowa (proponowana przez pierwszego $\mathrm{z}$ interlokutorów wskazanych $\mathrm{w}$ tytule) zostaje skonfrontowana $\mathrm{z}$ realizmem politycznym (znajdującym swego rzecznika w drugim uczestniku dialogu). Ziemianin, polemizując z koncepcjami Plebana, oświadcza:

I jakom WM dissensum $\mathrm{w}$ tym obiecował, tak słowa dotrzymywam i nie przypadam na to zdanie, a raczej, z odpuszczeniem WM, rze-

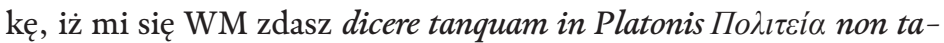
nquam in Romuli fece sententiam. Puściwszy albowiem swój rozsądek w szerokie pole dyszkursu wolnego, Rzeczpospolitą w swym umyśle stanowisz WM, jakoby to rzecz wolej i sił naszych była przemienić ją, jako i kiedy rozumiemy. (R, s. 62-63)

Łukasz Opaliński - dygnitarz i erudyta rozważający aktualne „postanowienie” Rzeczypospolitej z pełną świadomością różnych teoretycznych możliwości ujmowania spraw państwa nie bez powodu odwołał się do kultury antycznej, dostarczającej wyrazistych poświadczeń tego, jak silna polaryzacja zachodzić może w widzeniu tych spraw. Filozoficzna wrażliwość w ich ujmowaniu już przed wiekami podsuwała przeciwstawienia, po które sięgnął polski pisarz. Przeciwstawienia te mogą być pomocne $\mathrm{w}$ wyrażeniu napięć przenikających refleksję Marka Aureliusza - cesarza i filozofa, który pisząc w Rozmyślaniach o ułomnościach ludzi parających się polityką, notował: „Nie spodziewaj się państwa Platona" ${ }^{2}$. Przypomnijmy, że:

„Państwo Platona” było to wyrażenie przysłowiowe o sensie ściśle określonym. Nie oznaczało programu politycznego wyłożonego w dialogu wielkiego filozofa, lecz coś ogólniejszego, jakieś państwo, gdzie wszyscy obywatele stali się filozofami, a przez to ludźmi doskonałymi. Cyceron opowiada, że stoik Mucjusz Scewola bronił Rutillusa Rufusa tak, ,jakby sprawa toczyła się w państwie Platona”, czyli jakby przemawiał do samych filozofów. Gdzie indziej tenże Cyceron opowiada o Katonie Młodszym, że postępował on tak, jakby mieszkał w państwie Platona, nie w bagnie Romulusa. To także ma na myśli Marek Aureliusz. Niezwykle trudno jest zmienić ludzkie masy, przewartościować wartości, jakie ludzi pociągają,

${ }^{2}$ P. Hadot, Twierdza wewnętrzna. Wprowadzenie do "Rozmyślań” Marka Aureliusza, przeł. P. Domański, Warszawa 2004, s. 301. 
przekonania popychające ich do czynu; niezwykle trudno uczynić z nich filozofów ${ }^{33}$.

Rządzone przez filozofów państwo Platona ${ }^{34}$ jest bowiem nade wszystko „dziełem poświęconym kształtowaniu człowieka” ${ }^{35}$, a skomplikowany obraz modelowej organizacji życia zbiorowego stanowi tylko „tło dla skreślenia obrazu duszy ludzkiej” i zarysowania ideału paidei, w którym ludzka doskonałość wyraża się w poddaniu wszystkiego, „co jest w człowieku, jego części rozumnej" ${ }^{36}$. Zaznaczone przed chwilą podobieństwo spostrzeżeń Marka Aureliusza i Opalińskiego (nasuwające się oczywiście toutes proportions gardées) warte jest odnotowania, ponieważ wspólna im świadomość rozziewu między sferą ideałów i sferą faktów nie prowadzi ani w stronę wzniosłych spekulacji na temat państwa, ani też w kierunku pragmatycznej akceptacji brutalnych reguł gry politycznej. Wobec nierealności państwa Platona Marek Aureliusz uznaje, że ,istota rzeczy polega na skupieniu się na obecnym działaniu, politycznym i moralnym, jakkolwiek skromne by ono było. Czyń, czego Natura (czyli Rozum) żąda od Ciebie w tej chwili, nie daj się zwieść utopijnymi wizjami, jakże rozległymi" ${ }^{37}$. Choć ten rodzaj pogłębionej motywacji filozoficznej, którego świadectwem są Rozmyślania Marka Aureliusza, trudno przypisać Opalińskiemu, to również i jego dzieło $-\mathrm{z}$ uwzględnieniem wszelkich odmienności - zdaje się wyrażać skoncentrowanie na sprawach aktualnych. Na kwestiach rozpatrywanych rozumnie, uczciwie, z pełną świadomością ograniczonego oddźwięku, jaki w sferze postaw społecznych może wywołać Rozmowa Plebana z Ziemianinem - utwór wywodzący się z konkretnych „źródeł sejmowych" ${ }^{8}$, acz równocześnie aspirujący do tego, aby żywiołową dramaturgię sporów politycznych uczynić bardziej rzeczową i realistyczną, słowem: bardziej rozumną.

Wobec niejednoznacznej konkluzji Rozmowy (niepozwalającej na definitywne ustalenie skali i formy proponowanych reform

33 Ibidem, s. 302.

34 Platońskie ujęcie filozofa „wobec spraw państwa” charakteryzuje J. Gwiazdecka, Etyka Platona. O formie platońskiej refleksji moralnej, Kęty 2003, s. 110-123. Zob. też s. 102-108.

35 W. Jaeger, Paideia. Formowanie człowieka greckiego, przeł. M. Plezia, H. Bednarek, Warszawa 2001, s. 835.

${ }^{36}$ Ibidem, s. 941.

37 P. Hadot, op.cit., s. 301.

${ }^{8}$ Zob. S. Grzeszczuk, Ideologia i źródła sejmowe „Rozmowy Plebana z Ziemianinem" Łukasza Opalińskiego. W zmienionej wersji, zatytułowanej Dialog o granicach i paradoksach „naprawy Rzeczypospolitej” w XVII wieku, w: idem, Kocbanowski i inni, s. 299-345. 
ustrojowych), dalej zaś wobec trudności w określeniu, którą z postaci dialogu (Plebana czy Ziemianina?) uznać za wyraziciela stanowiska Opalińskiego - proponowana tu interpretacja zmierza do wykazania, że przesłanie utworu można ująć następująco. Otóż odżegnując się od państwa Platona i jego ideowego spadkobiercy Tomasza Morusa, autora „zmyślonej Utopijej” (R, s. 63), Opaliński odrzuca utopijny wzorzec myślenia, oparty na dwóch zaprzeczeniach: „nie tu i nie teraz”39. Ponieważ rozumne widzenie spraw państwa powinno wychodzić naprzeciw temu, co istotne „tu i teraz”, wszak „,To baczna, to rozsądna rada kontentować się takim postanowieniem ojczyzny, jakeś zastał, a o to się starać wszystkiemi siłami, abyś takież podał potomności” (R, s. 63). Liczenie się z realiami, z istniejącymi obyczajami i prawami - nawet ułomnymi - jest dezyderatem rozumności, co „każdemu w rzeczypospolitej będącemu brać w rozum należy i to nieomylnie wiedzieć [... " (R, s. 64). Wprowadzenie radykalnych zmian należy wykluczyć również dlatego, że pociągnęłyby za sobą mordy, rozlew krwi i bratobójcze walki. Rozum poucza więc, iż „odmiana niepodobna”, dlatego „wszelka rada, wszelki rozum nie potrafi, i szkoda się rozsądnemu zabierać na to, uważając, iż częstokroć poruszy chorobę lekarstwo niewczesne” (R, s. 66). Emendacja stosunków w państwie wyłaniająca się „inter orbitas usus et rationis” ( $\mathrm{R}$, s. 89) może więc mieć zasięg ograniczony, lecz jest godna starania, gdyż wolno oczekiwać po niej głębszej rozumności obywateli i zwiększenia udziału racjonalnych rozwiązań w życiu zbiorowości.

Dla przedstawionej propozycji odczytania znaczenie ma i to, że projektowanym adresatem Rozmowy Plebana z Ziemianinem jest odbiorca rozumny i rozsądny. To praca kierowana do czytelnika, który wyda o niej sąd ,z rozmysłem i bez afektu” (R, s. 5). Przedstawia treści, które „iudicium dictavit”, „, bacznych i rozsądnych uwagi godne" (R, s. 6), a przekazane z nadzieją, że znajdą swe miejsce „w zdrowym a bacznym rozsądku” (R, s. 9) odbiorców utworu.

Afirmacji rozumu i rozsądku (przejawiających się w „,bacznym" osądzie rzeczy) nieprzypadkowo towarzyszy ujemna ocena afektów $4^{\circ}$, charakterystyczna dla wielu racjonalistycznych teorii antropologicznych. Naganie podlegają posłowie „złymi uniesieni afektami” (R, s. 110), zwłaszcza chciwością, uporem, swarliwością, wybujałą ambicją. Umiłowana przez wielu „pry-

39 A. Krzewińska, Poczatki utopii w literaturze staropolskiej, Toruń 1994, s. 5.

$4^{\circ}$ Zob. też uwagi Opalińskiego na temat namiętności w Obronie Polski (OP, s. 193) oraz uczuć strachu i bojaźni zaślepiających rozum w poemacie Cośnowego (CN, s. 265). 
watna wolność” określona jest jako „niebaczny afekt” (R, s. 85). Pilną potrzebą życia publicznego, skażonego także nienawiścią i zawziętością podsycanymi przez klientelizm ${ }^{4 \mathrm{I}}(\mathrm{R}, \mathrm{s}$. 114-115), jest rozumne moderowanie afektów. Wymóg rozciągnięcia nad nimi racjonalnej kontroli trzeba sformułować tym dobitniej, że niewielu u nas zdobywa się na „chwalebne [...] afektu pomiarkowanie" (R, s. 113), którego budujących przykładów dostarcza historiografia rzymska.

Niełatwe zadanie czeka ludzi, którzy do racjonalnych środków zaradczych zechcą odwołać się w praktyce. Do powściągliwości w szacowaniu skuteczności rozumnych wzorów postępowania skłania obserwacja sejmu, w którym zasiada wielu posłów „baczenia miałkiego”, „bez rozsądku żadnego” (R, s. 31). „A lubo też jest niemało bacznych, rozsądnych, cnotliwych, życzliwych ojczyźnie, jednak łacno ich przemoże złych większa kupa" (R, s. 32-33). Powściągliwość ta konieczna jest tym bardziej, że autor Rozmowy Plebana zZiemianinem upominał się o korektę postaw, których często bezskutecznie domagała się staropolska literatura polityczna. Czy ponawianie apelu o ich zmianę nie było więc koniec końców mrzonką zrodzoną z nieposkromionych marzeń o państwie Platona? Przecząca odpowiedź na to pytanie możliwa jest pod warunkiem, że, jak zaznaczyliśmy, projektowi emendacji państwa przypisuje się ograniczoną moc sprawczą. Trzeba to powtórzyć zwłaszcza ze względu na zamierzenie pisarza, jakim było skłonienie uczestników życia publicznego do częściowej rezygnacji z przywilejów „złotej wolności” - najcenniejszej zdobyczy przodków, uzyskanej w efekcie ich wysiłku i ofiar, przy wsparciu łaski boskiej ${ }^{42}$, nie bez powodu zatem silnie zakorzenionej w zbiorowej emocjonalności sarmackiej. W tym stanie rzeczy potrzebą chwili jest skorygowanie zbyt afektywnego stosunku do wolności i powiązanie go z rozumnym podejściem do polityki. Nie przyświeca mu zamiar likwidacji wywalczonych swobód, lecz - przeciwnie - ich utrzymanie, wymagające jednak ograniczenia nadmiernej ekspresji wolności.

Tej linii rozumowania odpowiada stwierdzenie, że do zasady umiaru w korzystaniu z wolności przychyli się „każdy rozsądny, cnotliwy, ojczyźnie życzliwy" (R, s. 84), jak i postulowanie prawa, „które lubo nieco się zda umykać wolności, jednak w rze-

${ }^{4}$ Wyczerpującą analizę tego zjawiska przedstawia A. Mączak w swoich pracach: A. Mączak, Klientela. Nieformalne systemy władzy w Polsce $i$ Europie XVI-XVIII w., Warszawa 1994; idem, Nierówna przyjaźń. Układy klientalne w perspektywie bistorycznej, Wrocław 2003.

${ }_{42}$ C. Hernas, Zlota wolność (notatki do interpretacji), „Teksty” 1974, nr 4, s. $5-6$. 
czy samej oddala jej zgubę ostatnią, całość utwierdza i zachowuje" (R, s. 85). Rozum koryguje więc zwyrodnienia wolności przez odniesienie jej do wartości nadrzędnej - dobra wspólnego, wskazując, że dla pojmowania wolności zgubna jest zasada, którą streścić można w formule „wszystko albo nic”. Zasada ta, uczyniona dewizą pojmowania i odczuwania wolności, może obrócić się przeciw niej. Rozum, stojąc na straży wywalczonych swobód, usposabia więc do tego, aby nie pojmować ich w kategoriach radykalnej opozycji wolności i niewoli, lecz w bardziej zniuansowanych kategoriach różnych stopni wolności. Dodajmy, że wspomniane przed chwilą odniesienie do dobra wspólnego tkwi też u podłoża jeszcze jednego racjonalnego dezyderatu, który trudno przekuć na praktykę postępowania ludzi, a który sprowadza się do stawiania spraw publicznych ponad interesem prywatnym. Dezyderat ten ma szansę stać się zasadą kształtowania polityki wtedy, gdy przełoży się go na rozumną organizację obrad sejmu, tak więc: „Naprzód rozum pokazuje, że te materyje, które wszystkę Rzeczpospolitą zachodzą, pierwsze przed prywatnymi miejsce mieć słusznie mają” (R, s. 99; zob. też R, s. 105-107).

Racjonalna korekta obyczajów politycznych powinna wreszcie objąć kulturę żywego słowa ${ }^{43}$, zdominowaną przez popisy krasomówcze przeniknięte czczym werbalizmem, lekceważące rzeczową analizę spraw dyskutowanych na forum publicznym. Każdy rozumny zgodzi się z opinią, że rozwlekłe wystąpienia mówców, wśród nich senatorów, przeniknięte są „wymowy ostentacyją” (R, s. 94), próżnymi pochwałami czy niestosownymi w senacie żartami. Zgodnie $\mathrm{z}$ racjonalnym wzorcem dyskusji parlamentarnych za wysoce naganną uznać trzeba nieposkromioną rozwlekłość mów również dlatego, że w ich mocy leży wzbudzanie u słuchaczy gwałtownych namiętności ( $\mathrm{R}$, s. 109).

„Słów siła, rzeczy mało” (R, s. 32) - narzekał Opaliński w Rezmowie Plebana z Ziemianinem. Po latach natomiast, gdy w Poecie nowym krytycznie omawiał niektóre postacie współczesnej sobie twórczości uprawianej w mowie wiązanej, odmawiał miana poety temu, którego utwory cechuje „słów siła” pozbawiona „rozsądku” (PN, s. 310). Opowiadał się równocześnie za wzorem twórcy, którego poczynania podporządkowane są między innymi takim regułom tworzenia:

43 Zob. Kultura żywego stowa w dawnej Polsce, red. H. Dziechcińska, Warszawa 1989. 
Podaje koncept pełna rzeczy głowa -

Za tym posłuszne następują słowa,

Które zaś tak są potrzebnie sadzone,

Że nie może być żadne opuszczone

Bez zguby sensu i tyle rymowi

Służą, wielkiemu ile rozsądkowi,

Bo tu ustawnie ma na dobrej pieczy,

Aby ile słów, tyle było rzeczy. (PN, s. 312)

Nie sposób rozważać tu wszystkie problemy z bogatego repertuaru zagadnień metaliterackich zawartych w Poecie nowym. W kontekście zajmującej nas problematyki uwypuklenia wymaga rola „rozsądku”, który odpowiada za racjonalność proporcji między słowami a rzeczami. Ów wyeksponowany wyraźnie „rozsądek”, czy też, jak czytamy w innym miejscu poematu, „wielki rozsądek”, powołany jest także do współdziałania z „dowcipem” i korygowania właściwej mu inwencji ${ }^{4} 4$, przejawiającej się wielorako wśród dokonań barokowego konceptyzmu.

Racjonalistyczne ukierunkowanie postulatów Opalińskiego uwidacznia się następnie w charakterystyce modelowego poety jako podmiotu, którego aktywność poznawczą powinien cechować esencjalizm - ma on wyróżniać się „doskonałym rzeczy uważeniem” (PN, s. 312), „własnymi słowami/ Istotę rzeczy powinien wyrazić" (PN, s. 313). Z definiowanymi tak regułami twórczości i jej podstawami epistemologicznymi spójne są cele poezji jako sztuki, która, krocząc drogą zdrowego rozsądku, ma wskazywać drogę do dobra (PN, s. 321).

Poezja kultywująca „rozsądek” (opisywany też jako „wielki rozsądek” i „zdrowy rozsądek”) jest więc w Poecie nowym sojuszniczką moralistyki. Jej fundamentem jest rozum, który unaocznia człowiekowi jego eschatologiczne powołanie (PN, s. 321-322), pozwala dostrzec marność doczesnych przyjemności zmysłowych i oprzeć się ich urokowi (PN, s. 323) $)^{45}$. Podobnie jak $\mathrm{w}$ innych utworach, tak i w omawianym poemacie Opaliński, prezentując własne poglądy, odwoływał się do różnych, często odległych w czasie, autorów. W zakresie filozofii

44 B. Otwinowska, Karta duszy tworzacej. O niektórych kategoriach estetycznych polskiego baroku, w: Literatura i kultura polska po „potopie”, red. B. Otwinowska, J. Pelc, przy współudziale B. Falęckiej, Wrocław 1992, s. 100. Zob. też s. $99,103$.

$45 \mathrm{~W}$ Poecie nowym daje więc o sobie znać charakterystyczna dla baroku wrażliwość wanitatywna, wielorako obecna w poezji tej epoki. Zob. na ten temat wszechstronne studium D. Künstler-Langner, Idea „vanitas”, jej tradycje i toposy w poezji polskiego baroku, Torun 1996. 
moralnej obok ideowego patronatu Księgi Koheleta (parafraza jej drugiego rozdziału została wpleciona w tekst utworu) uwidoczniły się wątki stoickie i akcenty antyepikurejskie ${ }^{46}$. Z kolei koncepcje teoretyczne zawarte w Poecie nowym - bez watpienia w niejednym punkcie odpowiadające klasycystycznemu ideałowi poezji - ostatnio potraktowano nawet jako „prawdziwy manifest XVII-wiecznego klasycyzmu" ${ }^{47}$. Racjonalistyczne wątki poematu wzmacniają argumentację na rzecz usytuowania go w ramach klasycystycznej tradycji rozważań o literaturze. Cechujący poetykę klasycystyczną „, swoisty racjonalizm” - paralelny wobec racjonalistycznych nurtów myśli XVII stulecia, choć nie wywodzący się z nich, bo legitymujący się starszym od nich rodowodem - był jednym z jej najważniejszych i najbardziej symptomatycznych składników ${ }^{48}$.

Drogi poszukiwań intelektualnych Łukasza Opalińskiego, dla których inspiracją był racjonalizm, rozpościerają się między wzorcowymi modelami aktywności człowieka a odległą od nich sferą codziennych zachowańludzi. Autor Deofficiisi Poetynowego orędował za racjonalną organizacją państwa, za rozumnym dialogiem tworzących je ludzi, za rozsądnymi, służącymi pożytkowi moralnemu zasadami sztuki słowa. Realizm skłaniał go wszakże do tego, aby życie zbiorowości, które nie jest w stanie całkowicie sprostać wysokim wymaganiom rozumu - nie może wznieść się na poziom państwa Platona - uczynić choć w pewnym stopniu bardziej rozumnym. Ów realizm zadecydował o tym, że przesłanie Rozmowy Plebana z Ziemianinem dalekie jest od racjonalistycznego uzurpatorstwa czy racjonalistycznej naiwności, pełnej bezkrytycznego zaufania do mocy sprawczej tkwiącej w rozumie. W związku z tą ostatnią kwestią godne uwydatnienia jest i to, że w jego refleksji o rozumie, wieloma nićmi powiązanej z racjonalistycznymi tendencjami literatury polskiego baroku ${ }^{49}$, pojawiło się zagadnienie kompetencji i ograniczeń tej władzy poznawczej

${ }^{6}$ E. Lasocińska, „Cnota sama z mądrością jest naszym żywotem”. Stoickie pojęcie cnoty w poezji polskiej XVII wieku, Warszawa 2003, s. 29, 71-73, 122$-124,146-147,185$.

47 K. Mrowcewicz, Trivium poetów polskich epoki baroku: klasycyzm - manieryzm - barok. Studia nad poezja XVII stulecia, Warszawa 2005, s. 194, przypis 12.

$4^{8}$ S. Pietraszko, Doktryna literacka polskiego klasycyzmu, Wrocław 1966, s. 79-100.

49 Zob. G. Raubo, Światło przyrodzone. Rozum w literaturze polskiego baroku, Poznań 2006. 
człowieka, najciekawiej ujęte w utworze Coś nowego. Mówiąc o sprawach widniejących ponad horyzontem racjonalnego widzenia - o przerastających je tajemnicach wiary, nieuchwytnej pojęciowo architektonice nieba czy istocie żywiołów - pisarz, tym razem w kontekście odmiennym od spraw społecznych, dowiódł, że refleksja nad ludzką rozumnością może być pouczającą lekcją pokory.

\section{GRZEGORZ RAUBO}

\section{Between Everyday and "Plato's Republic": Rationalist Aspects of Lukasz Opaliński’s Work}

The article specifies the role of rationalism in the work of a distinguished Baroque author, Łukasz Opaliński. The source material for the study consists of: Rozmowa Plebana z Ziemianinem (1641), Polonia defensa contra Ioan[nem] Barclaium (1648), Cośnowego (1652), Pauli Naeoceli de officiis libri tres (1659), Poeta nowy (1661-1662).

Łukasz Opaliński stated that reason is the most important cognitive faculty of the human being. Reason makes it possible to understand the rules of natural law, which is the source of ethical action among humans, and brings on understanding of the eschatological aim of human life, that is salvation. The possibilities of rational explanation do not, however, encompass the mysteries of religious faith or the basic concepts of natural philosophy, such as the elements, which are the principal components of matter.

Rationalism belongs to the principal ideas of Opaliński's political philosophy. He opted for a rational organization of the state and for rational ways of solving social problems (he underscored the role of common sense, rational dialogue of citizens and rational responsibility for the common good). The political formation that is best suited for rationalization of social life is monarchy. Seeing it as a model government, the author realised that it could not be introduced in the Poland of the 17 th century, and consequently, apart from the eulogy of the monarchy, he proposed improvements in gentry democracy, especially in limiting of the "golden freedom".

An important sphere of externalization of Opaliński's rationalist ideals was his theoretical thought on literature. He critically evaluated some examples of Baroque art of conceit. He underscored the role of rational sources of creativity and rational discipline in structuring a literary work, and his postulates in this field were close to the concepts of classicist criticism.

Keywords: Łukasz Opaliński, Baroque, literature, rationalism, philosophy. 
Grzegorz Raubo - doktor habilitowany, profesor nadzwyczajny w Instytucie Filologii Polskiej UAM. Jego zainteresowania koncentrują się na historii idei w epoce baroku, głównie na związkach literatury z filozofią i nauką. Jest autorem książek: Barokowy świat cztowieka. Refleksja antropologiczna w twórczości Stanistawa Herakliusza Lubomirskiego (1997), Światto przyrodzone. Rozum w literaturze polskiego baroku (2006), „Ludzie się na górne zapatruja obroty". Astronomiczne konteksty literatury polskiego baroku (2011), Kalendarze, kurioza i rzeczy ostateczne. $Z$ zagadnień literatury popularnej wdawnej Polsce (2011). 